\title{
TANULÁSI PROBLÉMÁK MAGATARTÁSI ZAVAROKKAL KÜZDŐ GYERMEKEKNÉL
}

\section{REINHARDT MELINDA ${ }^{*}-$ KÖKÖNYEI GYÖNGYI ${ }^{* *}$}

* az ELTE PPK Személyiség- és Egészségpszichológia Tanszékének doktorandusza, a Csepeli Nevelési Tanácsadó pszichológusa reinhardt.melinda@ppk.elte.hu ** az ELTE PPK Személyiség- és Egészségpszichológia Tanszékének tanársegéde kokonyei@gmail.com

\begin{abstract}
Összefoglaló tanulmányunkban a problémás viselkedésü gyermekek tanulási zavaraival, nehézségeivel, illetve a tanulási zavarral, gyengeséggel küzdö gyermekek problémás viselkedésével foglalkozunk. Ennek kapcsán elsöként áttekintjük a hazai oktatási-nevelési rendszerben alkalmazott szakkifejezéseket. Majd a kutatási és gyakorlati tapasztalatok alapján elemezzük a normál intelligenciaövezetbe tartózó, magatartászavarral és/vagy deviáns viselkedéssel jellemezhető gyermekek beszédbeli, olvasási, irási, számolási képességeit, részképesség-zavarait és figyelmi, illetve emlékezeti folyamatait. A magatartászavarok és a depresszió, valamint a szorongás magas komorbiditása (együttjárása) pedig azt indokolja, hogy röviden arra is kitérjünk, a társuló pszichopatológiai kórképeknél milyen kognitív deficitek fordulnak elö. Végül néhány gyakorlati példával illusztráljuk, hogy a magatartási zavarok és a tanulási zavarok hogyan gerjeszthetik egymást.
\end{abstract}

\section{A sajátos nevelési igény fogalma}

A sajátos nevelési igény (SNI) fogalma már beépült a nevelési - oktatási szókincsbe, azonban az utóbbi időben tovább differenciálódott az, amire ez a terminus technikus vonatkozik. A sajátos nevelési igény nemzetközi (OECD) definíciója (Special Education Needs) alapvetően három nagyobb részterületet foglal magában (International Standard Classification of Education, 1997):

A. Fogyatékosság (disability): Jellemzően organikus eredetü rendellenességek, orvosilag egyértelmüen diagnosztizálhatóak, mint a hallássérülés, a látássérülés, a középsúlyos vagy a súlyos értelmi fogyatékosság, a halmozott fogyatékosság. Az érintett tanulók különböző szociális rétegekhez tartoznak.

B. Tanulási nehézségek (learning difficulty): Speciális tanulási nehézségeket mutató tanulók (például diszlexia, diszkalkulia). A tanulók sajátos nevelési igényei nem tartoznak dominánsan sem az A, sem a $\mathrm{C}$ kategória jellemzőihez. 
C. Hátrányos helyzet (disadvantage): A tanulók sajátos nevelési igényei elsődlegesen szociális-gazdasági, kulturális és/vagy nyelvi tényezőkből erednek.

\section{Sajátos nevelési igény hazai viszonylatban}

Egy hazai felmérés (Csányi, 2007) jelentős átfedést talált a különböző SNI kategóriák (enyhén értelmi fogyatékos, közepesen értelmi fogyatékos, autista, beszédfogyatékos) és a szociális problémák, azaz a hátrányos helyzet jelenléte között. Ez azt implikálja, hogy a nemzetközi (OECD) felosztás a magyar körülmények esetében csak módosítva alkalmazható: nem tudjuk elkülönült kategóriaként kezelni a hátrányos helyzetüek csoportját, a szociális hátrányok sajátosan rátevődnek a sajátos nevelési igényre.

Az említett hazai felmérés (Csányi, 2007) arra is rámutatott, hogy a sajátos nevelési igényü csoportokon túl számos olyan gyermek van, akiknek szintén nehézséget okoz valamilyen oknál fogva a tantervek teljesítése. Ezek a tanulók ritkán részsülnek kiegészítő támogatásban (például korrepetálásban), azonban a pedagógusok és az osztályközösség energiáit, figyelmét ugyancsak lekötik.

Érdemes megjegyezni, hogy a különböző országok között jelentős eltérések vannak a sajátos nevelési igénnyel diagnosztizált tanulók létszámában. Az UNESCO kiegészítő támogatásra a tanulóknak kb. 10 százalékát javasolja. Nagy-Britanniában például az összes tanuló 13 százalékát sorolják a tanulási nehézségekkel küzdők közé, míg Finnországban az iskolások 23 százalékát (Equity in Education, OECD, 2004). A magyar SNI csoport aránya ettől elmarad: a 2004/2005-ös tanévben például a nemzetközi (ISCED) besorolás szerinti A és B kategóriákba együttesen az összes tanuló 8,4 százaléka volt valamilyen szakvéleménnyel besorolt (Csányi, 2007).

\section{Törvényi háttér}

A hazai gyakorlatba a 2007/2008-as tanév indulásával vezették be a sajátos nevelési igény differenciáltabb meghatározását. A Közoktatási Törvény 121. §-a szabályozza, ki tekinthető sajátos nevelési igényü gyermeknek, tanulónak: „Az a gyermek, tanuló, aki a szakértői és rehabilitációs bizottság szakvéleménye alapján a) testi, érzékszervi, értelmi, beszédfogyatékos, autista, több fogyatékosság együttes előfordulása esetén halmozottan fogyatékos, a megismerö funkciók vagy a viselkedés fejlődésének organikus okra visszavezethető tartós és súlyos rendellenességével küzd” (121. §/1/ 29/a pontja), illetve b) ,a megismerő funkciók vagy a viselkedés fejlődésének organikus okra vissza nem vezethető tartós és súlyos rendellenességével küzd" (121. §/1/ 29/b pontja). A rendellenesség hosszantartó, súlyos zavart jelent, melynek kóreredete - feltehetőleg - biológiai eredetü. Az organikus háttér meglétét, illetve hiányát a Tanulási Képességet Vizsgáló Szakértői és Rehabilitáci- 
ós Bizottság gyermekneurológusa vagy gyermek- és ifjúságpszichiátere vizsgálhatja ki, bizonyíthatja. A hivatkozott törvény 30 . $§(1)$ bekezdése szabályozza azt is, hogy rehabilitációs célú órakeret terhére „a sajátos nevelési igényü gyermeknek, tanulónak joga, hogy különleges gondozás keretében állapotának megfelelö pedagógiai, gyógypedagógiai, konduktív pedagógiai ellátásban részesüljön attól kezdődően, hogy igényjogosultságát megállapították."

\section{Zavarok, nehézségek, gyengeségek}

\section{Tanulási zavarok}

Mind az SNI a), mind az SNI b) kategóriába sorolt tanulóknál hangsúlyosan előfordulnak - izoláltan vagy kevert formában - tanulási zavarok és beilleszkedési zavarok.

A tanulási zavarok első definícióját a Kirk és Bateman (1962) szerzőpáros adta, amely több mint negyvenöt év alatt alig változott. Eszerint a tanulási zavar olyan elmaradás, rendellenesség vagy megkésett fejlődés a beszédbeli, olvasási, írási, számolási folyamatokban vagy más iskolai tantárgyakban, amelyet lehetséges agyi diszfunkció és/vagy emocionális, vagy viselkedési zavar által okozott pszichológiai hátrány eredményez. Hátterében nem értelmi fogyatékosság, nem érzékszervi hiányosság és nem kulturális vagy oktatási tényezők állnak.

Berk (1983) definíciójában összefoglalva: a tanulási zavar olyan gyüjtőfogalom, amely a figyelem, a beszéd, az olvasás, az írás, illetve a matematikai képességek elsajátítása terén mutatkozó jelentős nehézségek heterogén csoportjára utal. A zavarok eredetét a központi idegrendszer diszfunkciójában látja.

A jelenlegi konszenzus szerint a tanulási zavarral küzdő gyermekek közé az ép értelmi képességekkel rendelkező, normál intelligenciaövezetbe tartozó, érzékszervi fogyatékossággal nem bíró, azonban ezek ellenére az írás, olvasás és számolás technikájának elsajátításában nehézségekkel küzdő tanulókat soroljuk (Porkolábné, 2002). A tanulási zavarok spektruma igen széles és sokszínü: többféle képességhiányt lefed. Maga az elnevezés egy általános, összefoglaló kifejezés, amelybe egy képességdeficitekkel küzdő heterogén csoportot helyezünk. Ebbe az összefoglaló elnevezésbe „szorítjuk” mind a figyelmi funkciókban, mind a beszédkészségben, mind az olvasási, írási, számolási készségek elsajátításában és alkalmazásában akadályozottakat (Gyarmathy, 1998).

\section{Specifikus tanulási zavarok}

Az önmagában is heterogén specifikus tanulási zavar kategória a sajátos nevelési igény egyik jelentős részét alkotja. A különböző - eredetükben és tüneti megjelenésükben összetett és változatos - készséghiányokra számos elnevezést vett át, illetve alkotott a magyar szakirodalom. Így például tanulási zavarok, tanulási nehézségek, tanulási rendellenességek, specifikus tanulási zavarok, POS (pszicho-organikus 
szindróma) (Wolfensberger és Haessing, 1985/1992), MCD (minimális cerebrális diszfunkció) (Fritz, 1984/1992), részképességzavar, szenzoros integrációs zavar, diszlexia, diszgráfia, diszkalkulia (Gyarmathy, 2007) ${ }^{1}$.

A mentális zavarok amerikai diagnosztikus rendszere, a DSM-IV (2001) a tanulási zavarok (korábbi elnevezéssel iskolai készségek zavara) körébe négy kategóriát sorol:

1. olvasási zavar (F81.0)

2. $\quad$ írásbeli kifejezés zavar (F81.1)

3. számolási zavar (F81.2), illetve

4. máshová nem osztályozható tanulási zavarok (F81.9).

Tanulási zavar akkor diagnosztizálható, ha „az olvasási teljesítmény (F81.0), vagy az íráskészség (F81.1), vagy a számolási képesség (F81.2) egyénileg, standardizált tesztekkel vizsgálva, lényegesen alatta marad a személy biológiai kora, mért intelligenciája vagy a kor szerinti képzettség alapján elvárhatónak.” Továbbá a zavar ,jelentősen kihat az iskolai teljesítményre, vagy az olvasási jártasságot/az íráskészséget/a számolási képességet igénylő mindennapi élettevékenységekre." Valamint, „ha érzékelési deficit van jelen, az olvasási, íráskészégbeli, számolási nehézségek meghaladják az ahhoz rendszerint társuló zavar mértékét." (DSM-IV, 2001, 42-43. o.) Ebben a rendszerben a máshová nem osztályozható tanulási zavarokhoz tartoznak ,azok a tanulási zavarok, amelyek nem teljesítik egyik specifikus tanulási zavar kritériumait sem, a kategória mindhárom terület problémáit magában foglalja (olvasás, írásbeli kifejezés, számolás), amelyek együttesen befolyásolják az iskolai teljesítményt." (DSM-IV, 2001, 44. o.).

Az európai diagnosztikus osztályozási rendszer, a BNO-10 (1998) az iskolai teljesítmény specifikus fejlődési rendellenességeiről beszél, melyeket olyan zavarokként határoz meg, melyekben „a készségek megszerzésének a normális menete válik zavarttá”, ami „nem egyszerüen a tanulási lehetőség hiányának, mentális retardációnak vagy szerzett idegrendszeri trauma vagy betegség következménye." Ide sorolja:

1. a meghatározott olvasási zavart (dyslexia, F81.0)

2. az írás zavarát (dysgraphia, F81.1)

3. az aritmetikai készségek zavarát (dyscalculia, F81.2)

4. az iskolai készségek kevert zavarát (F81.3)

5. az iskolai készségek egyéb fejlődési zavarát (F81.8)

6. és az iskolai készségek külön meg nem nevezett fejlödési zavarát (F81.9).

\footnotetext{
${ }^{1}$ Az elnevezés bizonytalansága az angolszász területen is szembetűnő. Nagy-Britanniában ezeket a készséghiányokat a „specific learning difficulties” (SLD) kifejezéssel jelölik, az amerikai szakirodalomban pedig a „learning disabilities” (LD) terminussal. Komoly félreértésekre adhat azonban okot, hogy az amerikai elnevezés az angliai gyakorlatban a mentális retardáció miatt kialakult tanulási nehézséget jelöli (Gyarmathy, 2007).
} 
A diszlexia egyik fö jellemzője, hogy ezek a tanulók a klasszikus oktatási gyakorlatban nem képesek eljutni a nyelvhasználat olyan fokára, amely lehetővé tenné az értelmi képességeiknek megfelelő szintü olvasás, írás és helyesírás elsajátítását (Sauvageot és Métellus, 2006). Ezek a hiányosságok pedig - hiszen az (írásbeli) nyelvhasználat a társadalmi élet alapköve: biztosítja az információátadást generációról generációra, szerződéseket rögzít stb. - számos frusztrációt eredményeznek.

Berk (1983) megjegyzi, hogy ugyan a tanulási zavar előfordulhat más hátráltató sérülés (például érzékszervi gyengeség, társas-érzelmi zavarok) vagy környezeti hatás (például kulturális különbségek, nem megfelelő oktatás, pszichogén faktorok) kíséretében, azok hatásának mégsem egyenes következménye. Lényeges tehát, hogy a specifikus tanulási zavarok nem magatartási zavarok talaján „keletkeznek”, azonban sok esetben - azokkal párhuzamosan - másodlagos tünetként jelennek meg. Így ha nem történik meg idejében a specifikus tanulási zavar felismerése, diagnosztizálása, specifikus módszerekkel történő ellátása, korrekciója, akkor a meglévő, de fel nem tárt tanulási nehézséghez beilleszkedési, magatartási problémák társulhatnak, komoly, súlyossá váló tünetegyüttest eredményezve. A következőkben ezért tekintsük át a magatartási zavarok fogalomkörét.

\section{Magatartási zavarok}

A problémás viselkedés rendkívül széles spektrumát többféle szempontból szemlélhetjük, például a súlyossági fok szerint, vagy aszerint, hogy milyen mértékben akadályozzák a gyermek fejlődését, adaptív müködését, örömképességét, szociális kapcsolatait (Vikár, 1980; Ranschburg, 1998), azaz szubjektív jóllétét, illetve menynyire veszi igénybe környezete türőképességét (lásd az internalizáló és externalizáló viselkedési problémák megkülönböztetését (például Gádoros, 1996; Perczel Forintos et al., 2005).

Súlyossági, az élethelyzetekre való kiterjedés mértéke szerinti csoportosítás alapján a következő spektrumot vázolhatjuk fel: beilleszkedési zavar - viselkedészavar - magatartászavar - deviáns viselkedés (Felleginé, 2004).

\section{Beilleszkedési zavarok}

A beilleszkedési zavarok közé az aktivitás és a figyelem zavarát, valamint a hiperkinetikus magatartászavart sorolhatjuk. A szakirodalomban ADHD-nak rövidített (Attentional Deficits/Hyperactivity Disorders), ún. figyelemhiányos/hiperaktivitás zavar tünetegyüttes (DSM-IV) hátterében neurológiai elváltozás áll, társulhatnak hozzá tanulási zavarok, de mégis elkülönítjük tőlük (Gyarmathy, 1998). A hazai diagnosztikában használt BNO-10 rendszer az aktivitás és a figyelem zavarait a viselkedés és az érzelmi-hangulati élet rendszerint gyermekkorban vagy serdülőkorban jelentkező zavaraihoz sorolja, míg a diszlexiát, a diszgráfiát és a diszkalkuliát az iskolai teljesítmény specifikus fejlődési rendellenességeihez. 
Egy tágabb meghatározás szerint a beilleszkedési zavar a problémás viselkedés spektrumának a legenyhébb szintjét képviseli: egy új közösséggel való kapcsolatfelvétel vagy kapcsolat-fenntartás nehézségeit jelöli (Felleginé, 2004), ez adódhat leválási nehézségekből, kötődési problémákból, idegen helyzetekkel, emberekkel kapcsolatos félelmekből, szorongásokból, vagy például a szabálykövető magatartás kisebb fokú éretlenségéből, illetve a szociális adaptáció hiányosságából (Ranschburg, 1998).

Viselkedészavar, magatartászavar, deviáns viselkedés

Viselkedészavar terminuson a viselkedés alkalmi jellegü, a megszokottól eltérő, kedvezőtlen változását értjük, amely körülményektől, állapottól, személyektől függő helyzeti reakció (például bizonyos órákon jelentkezik csak a fegyelmezetlenség) (Felleginé, 2004). A magatartászavar már tartósan fennálló problémát jelez. Ekkor a gyermek az életkorából és élethelyzetéböl adódó viselkedési követelményeknek, szabályoknak tartósan nem tud megfelelni, lázad ezek ellen, ellenáll azoknak (például hiányzások, verekedések, bohóckodás minden tanórán) (Zsidi, 1997). A „súlyossági spektrum" másik véglete a deviáns viselkedések köre, ahol már a társadalmilag elfogadott magatartási és erkölcsi normák megsértése történik, aszociális reakciók jelentkeznek (például szerhasználat, csavargás, lopás) (Vikár, 1980).

Egy sajátosan hazai kategória: beilleszkedési, tanulási, magatartási nehézség

A sajátos nevelési igénytöl - a hazai törvényi szabályozás szerint - elválik az ún. beilleszkedési, tanulási, magatartási nehézség (BTMN) kategóriája, amely a különböző területeken való tanulási nehézséget jelöli és/vagy a beilleszkedési, magatartási problémák széles tárházát. Az ilyen tanulók felmentést kapnak az érintett részképesség (például helyesírás tantárgyrész), illetve tantárgy (például idegen nyelv) értékelése és minősítése alól (1993. évi LXXIX. KTv. 30. § (9) pontja), valamint a csoport, osztály létszámának számításánál ők is - hasonlóan a sajátos nevelési igényü tanulók bizonyos csoportjaihoz - két főnek számítanak (1993. évi LXXIX. KTv. III. Melléklet 3. pontja). ${ }^{2}$

\section{Tanulási gyengeség}

Sok esetben a probléma, a zavar, a hiány súlyossága nem indokolja sem a sajátos nevelési igény, sem a beilleszkedési, tanulási, magatartási nehézség megállapítását, mégis észlelhető az adott tanulónál tanulási gyengeség. Ez olyan elmaradást jelent,

\footnotetext{
${ }^{2}$ BTMN diagnózis óvodáskorú gyermekek esetében is adható, ekkor - hasonlóképpen az 1-3. osztályos tanulókhoz - még csak beilleszkedési - tanulási - magatartási nehézség veszélyeztetettségröl beszélhetünk.
} 
amely többségi pedagógiai eljárásokkal kezelhető, kezelendő, differenciált segítségadás formájában korrigálható.

Mind a sajátos nevelési igényü, mind a beilleszkedési, tanulási, magatartási nehézséggel, valamint a tanulási gyengeséggel küzdő gyermek fokozott pedagógiai támogatást, speciális nevelési-oktatási módszerek adaptálását igényli a pedagógiai repertoárba. Mindez többletmunkát, „többletidőt”, plusz energiák, készségek mozgósítását igényli a pedagógustól és a kapcsolódó intézményhálózattól (például iskolapszichológus, a Nevelési Tanácsadó pszichológusai, gyógypedagógus, fejlesztőpedagógus).

Láthatjuk, hogy igen nehéz kiigazodni a diagnózisok, „címkék”, megjelölések útvesztőjében. Megkönnyítheti azonban a tisztánlátást, ha mérlegeljük az adott jelenség (például számolási nehézség) eredetét (például értelmi fogyatékosság, diszkalkulia, tanulási nehézség, tanulási gyengeség), tüneteit (például kialakulatlan helyiérték- és mennyiségfogalom, szöveges feladatok megoldásának nehézsége), lehetséges kimeneteit (például korrepetálással felzárkóztatható-e) és kezelését (például gyógypedagógus vagy pedagógus végezheti).

\section{A sajátos nevelési igényü gyermekek ellátása}

A sajátos nevelési igény esetében a gyermek ellátása történhet specifikus, szegregált intézményben, valamint integrált keretek között. Az integrált nevelés-oktatás, azaz a sajátos nevelési igényü gyermekek többségi közösségben történő nevelése, oktatása hazánkban is egyre elfogadottabb, népszerübb és - amennyiben nem ún. ,rideg integrációról" van szó - hatékonyabb forma (például Csányi, 1991, 2000). A mindennapi gyakorlatban egyre több óvoda, iskola vállalja fel, hogy sajátos nevelési igényü gyermekeket is ellát a többségi osztályokban. Ez megváltozott szemléletmódot, módszereket, eszközöket, azaz új ismeretek, készségek elsajátítását követeli meg a pedagógusoktól. Sajátos nevelést, oktatást, ami egy (még inkább) többszereplőssé váló rendszer minden érintettjére kihat, így az integrált tanuló mellett az integrációt felvállaló intézmény, pedagógus és osztályközösség mindennapjaira, viszonyulásaira egyaránt.

\section{Beilleszkedési zavarok, magatartási zavarok, deviáns viselkedés és a tanulási zavarok összefüggései}

Álljon a tanulási zavar, nehézség vagy gyengeség hátterében bármilyen tényező, maga a fennálló probléma számos frusztrációval jár a gyermek számára. Az iskolai lét kudarccá válik (Holt, 1991), ami ellen valahogyan védekezni kell. A jól ismert „régi törvény” szerint a frusztrációra gyakran agresszió a válasz. Agresszió, vagy valamilyen más, viselkedésben megjelenő probléma, de gyakori - a „szabad szemmel” sokáig nem is észrevehetö, lappangó - egyéb pszichés zavar (például szoron- 
gás, a hangulat zavarai) társulása. A tanulási nehézségekhez gyakran párosul éppen ezért magatartászavar. Így például tévé- és számítógépfüggés, csalás, hazugság, a házi feladat elhanyagolása és az abból származó krónikus lemaradás, zárkózottság, visszahúzódás, szociális izoláció, agresszív, uralkodó magatartás a társakkal szemben (például más gyermek zsarolása), szélsőséges esetben iskolakerülés (György, 1978; Selikowitz, 1997). Nemi különbségek figyelhetők meg abban, hogy a tanulási nehézségekhez milyen pszichopatológia társul gyakrabban. Lányok esetében az olvasási nehézségekhez inkább internalizáló zavarok, míg fiúknál externalizáló zavarok társulnak (Willcutt és Pennington, 2000). A leggyakoribb társuló zavar azonban úgy tünik, hogy a figyelemhiányos/hiperaktivitás szindróma (ADHD) (Willcutt et al., 2001). Több felmérés arra mutat rá, hogy ADHD-ban igen magas arányban (30-80\%) fordulnak elő tanulási zavarok (például Barkley, 1990; Richters et al., 1995), ezek közül is kimagaslik a diszkalkulia komorbid előfordulása (Márkus et al., 2000). Egy óvodásokkal végzett ikervizsgálatban az is kiderült, hogy a preolvasási készségek ${ }^{3}$ és a figyelemhiány közötti összefüggés alacsony, de szignifikáns, míg a hiperaktivitással és impulzivitással nem volt kapcsolat. Az olvasási képességek és a figyelemhiány közötti kapcsolatért feltehetően közös genetikai hatás tehető felelőssé (Willcutt et al., 2007).

Ugyanakkor az is gyakori, hogy a meglévő magatartászavar, illetve a háttérben húzódó pszichikus problémák vezetnek a figyelem, az emlékezet, a percepció, a gondolkodás, azaz a tanulás részmechanizmusainak problémás müködéséhez - kialakítva a tanulási zavart. Sokszor a tanulási és a magatartási zavarok olyan szorosan összefonódnak, hogy együttes jelenlétük kölcsönösen erösíti a másikat (Sutherland, Lewis-Palmer, Stichter és Morgan, 2008).

Felmerült az a kérdés, hogy milyen tényező állhat a problémás vagy antiszociális viselkedés és a tanulási zavarok kapcsolatának hátterében. Elsősorban az olvasási nehézség és az antiszociális viselkedés kapcsolatát vizsgálták. Egy újabb ikervizsgálat eredményei megerősítik, hogy az olvasási problémák és az antiszociális viselkedés kapcsolatáért elsősorban környezeti tényezők felelősek, föképpen a fiúk körében (Trzesniewski et al., 2006). Ebben a vizsgálatban arra is fény derült, hogy a két probléma egymást erősítö kapcsolatban áll, a rosszabb olvasási teljesítmény antiszociális viselkedéshez vezetett, és fordítva.

Több longitudinális vizsgálatban igazolták azt is, hogy a gyermekkortól kezdődően viselkedési problémákkal küzdő gyerekek verbális képességei és így verbális intelligenciájuk alacsonyabb, azonban ez a hátrány még három éves korban nem érhetö tetten, csak később, az általános iskolai években (Raine et al., 2002; Raine et al., 2005). Ez arra utalhat, hogy a rosszabb verbális képességek gyermekkorban

\footnotetext{
${ }^{3}$ A pre-olvasási készségek (olvasási előismeretek) szükségesek az olvasás elsajátításához (például a gyermek tudja, hogy a szavak hangokból állnak, így tud két ugyanolyan hanggal kezdődő szót mondani, vagy egy adott betüvel azonosakat ki tud választani több betü közül, felismeri a rímelő szavakat).
} 
szerzett hátrányként értelmezhetők. Emellett Raine és munkatársai (Raine et al., 2005) azt találták, hogy ezeknél a gyerekeknél a téri képességek terén is kimutathatók deficitek, ezek azonban már három évesen is megmutatkoznak. A szerzők szerint a három éves kori hátrány jobb félteke müködési deficitet jelez, amely egyben a jobb félteke által vezényelt más funkciók - így például érzelemszabályozás, korai kötődés - müködésére is kifejti hatását.

A magatartászavar tulajdonképpen szocializációs zavar, amely a társadalmi beilleszkedéshez szükséges szerepviselkedések, az azokkal kapcsolatos ismeretek és képességek elsajátításának, illetve alkalmazásának nehézségeit foglalja magában. A szociális tanulás gyengeségei, problémái következtében a társas kapcsolatokban és együttmüködésben zavar, önszabályozási nehézség lép fel (Bödör, 1991). A magatartásproblémák érinthetik a motivációs-akarati szférát (például az érdeklődés gyengesége, közösségi passzivitás, indítékszegénység, döntési nehézség), az érzelmi-indulati életet (például a társas érzelmek - együttérzés, bizalom - viselkedésmintáinak gyengesége, szorongás, ingerlékenység, hangulati labilitás, közöny), a regulációs területet (például önértékelési zavar, önkontrollzavar, a magatartás kritikátlansága). Magában foglalhatja továbbá a motoros funkciók zavarát (például hipermotilitás, meglassult pszichomotoros tempó), vagy a szociális képességek hiányosságait (például a konfliktus-megoldási képességek gyengesége, a szerepviselkedés, a kapcsolatteremtési és -tartási skillek hiányosságai). Az ezeken a területeken való elmaradás kihat az iskolai készségekre, a tanulás folyamán müködtetett kognitív funkciókra is: így a szenzomotórium, a figyelem, az emlékezet és a gondolkodás területeire.

A felsorolt, elsősorban önszabályozási problémák arra utalnak, hogy magatartászavarokban (ODD, CD) ${ }^{4}$ a végrehajtó funkciók gyengébben müködnek (Moffitt, 1993; Moffitt és Caspi, 2001). A végrehajtó funkciók olyan magasabb rendű kognitív funkciók csoportját jelentik, mint kezdeményezés, tervezés, kognitív flexibilitás, absztrakció, döntéshozatal, vagyis együttesen a kontextuálisan megfelelő viselkedés kivitelezésért felelősek (ld. Csépe, 2005). Fizikai agresszióval jellemezhető gyerekeknél speciális neuropszichológiai teszteken a válaszperszeveráció - mint a végrehajtó funkciók egyik mutatója - magasabb elöfordulását mutatták ki (Séguin et al., 2002). Óvodás gyerekeknél az oppozíciós zavar tünetei és a válaszgátlás (Brocki et al., 2007), valamint az agresszív viselkedés és a válaszgátlás között találtak kapcsolatot (Raaijmakers et al., 2008). Könnyen belátható, hogy a válaszgátlás problémai hozzájárulhatnak a tanulási és iskolai problémákhoz. Egy 2000-ben elvégzett vizsgálatban (Giancola és Mezzich, 2000) magatartászavarral (CD) diagnosztizált 14-18 éves kor közötti lányok mintáján a kutatók azt találták, hogy a nyelvi

\footnotetext{
${ }^{4}$ ODD = oppozíciós magatartás zavar: negativisztikus, ellenséges, dacos viselkedés, mely legalább hat hónapon keresztül fennáll, föleg kisebb gyermekeknél (DSM-IV, 1994). CD (conduct disorder): kóros agresszióval járó viselkedészavar.
} 
deficitek és antiszociális viselkedés közötti kapcsolatot a végrehajtó funkciók alacsonyabb szintje közvetítette (az életkor és a szocioökönomiai státusz kontroll alatt tartása mellett). Bár ahogy eddig is láttuk, vannak arra vonatkozóan megerősítő adatok, hogy a magatartászavarok közül az ODD és a $\mathrm{CD}$ a végrehajtó funkciók zavarával társul, néhány vizsgálat arra utal, hogy ezért az ADHD komorbid mivolta (együttjárása) (Berlin és Bohlin, 2002), vagy éppen az ADHD tüneteinek szubklinikus megjelenése lehet a felelős (Brocki et al., 2007). Ismert, hogy az ADHD mellé leggyakrabban CD vagy ODD társul (Loeber et al., 2000).

Nehezen kezelhető óvódásokkal végzett vizsgálatok igazolják, hogy az érzelmi megértés, a mentalizációs képesség alacsonyabb szintje már iskoláskor előtt megjelenik (Hughes et al., 1998), sőt már a két éves elmeolvasási képesség ${ }^{5}$ szignifikánsan magyarázza a négy éves kori problémás viselkedést (Hughes és Ensor, 2007). Érdemes megjegyezni, hogy nemcsak egyéni, hanem családi jellemzők - például a szülők nevelési stílusa - is magyarázzák a későbbi problémás viselkedést, illetve ha az egyéni és családi kedvezötlen jellemzők egyaránt jelen vannak, akkor nagyobb annak az esélye, hogy a gyermek problémás viselkedésü lesz már az óvodában (Hughes és Ensor, 2007). A különböző kutatások szerint a mentalizációs képesség (elmeolvasás, theory of mind) és a végrehajtó funkciók szoros kapcsolatban állnak (Hughes et al., 1998), illetve fent láthattuk, hogy a verbális képességek és a magatartászavarok közötti kapcsolatban a végrehajtó funkciók deficitjét közvetítő tényezőnek tartják (Giancola és Mezzich, 2000). Ezt a kapcsolatot Hughes és Ensor (2008) óvodáskor előtt is igazolta. A kétéves kori verbális képességek és a négy éves kori problémás viselkedés közötti kapcsolatot a három éves kori végrehajtó funkciók közvetítették Egyes vizsgálatok a pragmatikus nyelvhasználat deficitjeit mutatták ki CD-s gyerekeknél (Gilmour et al., 2004), amely felelős lehet a szociális kommunikáció nehézségeiért ebben a csoportban. A szociális kompetencia nehézségeit mind ADHD-vel, mind ODD/CD-vel, illetve mindkét problémával diagnosztizált serdülöknél kimutatták (Clark et al., 2002).

\section{Tanulási zavarokhoz társuló társas és érzelmi problémák}

A különböző részképesség-zavarok (például koordinálatlan nagy- és finommotórium, motoros nyugtalanság, az impulzuskontroll zavarai, a koncentrációs és emlékezési zavarok) állandó konfliktusforrások lehetnek egy osztályban, csoportban.

\footnotetext{
${ }^{5}$ A naiv tudatelmélet az arra való kognitív kapacitásunkat jelöli, hogy képesek vagyunk a cselekvők viselkedését megérteni, magyarázni és bejósolni különböző mentális állapotok tulajdonítása által. A viselkedést ezeknek a kölcsönhatásaiból, azok oki következményeként eredeztetjük. Mindez implicit tudáson alapul, müködtetése automatikus, gyors folyamat (Perner et al., 2002). A személyközi viselkedést tehát mentális állapotok tulajdonítása révén vagyunk képesek megérteni. Fónagy és Target (2005) továbbá amellett érvel, hogy a szelf szervezödésében és az érzelmi szabályozásban is döntő tényező a mentalizációs képesség, amely a korai kötődéskapcsolatokban formálódik.
} 
Gyakran a megjelenő magatartásproblémák reaktív viselkedészavarokként értékelhetőek: a tanulási zavarral küzdő gyermek bizonyos szituációkban - akaratán kívül - retorziót, agressziót, büntető reakciót vált ki társaiból (például koordinálatlanul szaladva meglöki a másikat, aki ezért szintén meglöki őt), amire ismételten - most már tudatosan - ő maga is támadó választ ad.

A tanulási zavarral küzdő gyermekek iskolai alkalmazkodási problémáit számos kutatás leírta (Morrison és Cosden, 1997; Wenz-Gross és Siperstein, 1998). Tanulási és kognitív nehézségeik mellett több társas és érzelmi problémával kell szembenézniük ${ }^{6}$ : például a társak fokozott mértékü elutasításával, magányossággal, alacsony önértékeléssel, a szociális összefüggések meglátásának nehézségeivel, a depresszió és a szorongás megemelkedett szintjével (Morrison és Cosden, 1997; Culbertson, 1998). A kutatók szerint ugyanazok a neurológiai problémák lehetnek felelősek a tanulási zavarral küzdő gyerekek rossz iskolai teljesítményért, mint amelyek a társas és érzelmi percepcióban és interpretációban mutatkozó nehézségek hátterében állnak, és amelyek így meggyengítik kapcsolataikat társaikkal és a felnőttekkel (Spafford és Grosser, 1993; Bender és Wall, 1994). A neuropszichológiai problémák közül több vizsgálatban is a munkamemória deficitjeire mutattak rá, ezt kapcsolják össze az olvasási és számolási nehézségekkel, valamint a szövegértésben (reading comprehension) mutatott alacsonyabb teljesítménnyel (Swanson és Siegel, 2001; Swanson és Jerman, 2007; Swanson és Kim, 2007).

Már korábban rámutattak arra, hogy a tanulási zavarral küzdő tanulók társas készségei szegényesebbek, ami nehézségeket okoz a társas támogatás mobilizálásában, ha az szükséges lenne (Carlson, 1987; Feigin és Meisgeier, 1987). Egy erre irányuló vizsgálatba (Geisthardt és Munsch, 1996) tanulási problémás és nem problémás vontak be. A hallgatóknak 11 stresszteli iskolai eseményt kellett megítélniük aszerint, hogy előfordult-e velük, illetve mennyire ítélték azt megoldhatónak. Felmérték továbbá a résztvevők megküzdési stílusát és társas támogatottságát is. Az eredmények szerint a két csoport között nem mutatkozott különbség az észlelt stressz szintjében. A tanulási zavarral küzdő serdülők azonban többször hiányoztak az iskolából és kisebb valószínüséggel vettek részt különböző iskolai aktivitásokban, mint a tanulási zavarral nem küzdő társaik. A tanulási zavaros serdülők az iskolai stresszes eseményekkel való szembenézés során föként elkerülő megküzdési stílust alkalmaztak. Jellemző volt rájuk az is, hogy ha iskolai vagy interperszonális problémával néztek szembe, kevesebb társas támogatást kértek kortársaiktól. Martlew és Hodson (1991) tanulási zavarral küzdő és azzal nem küzdő tanulók kortárskapcsolatait hasonlították össze angliai iskolákban. Adataik megfigyeléseken és interjúkon alapultak. Eredményeik szerint a tanulási zavarokkal küz-

\footnotetext{
${ }^{6}$ A kötetben a megismerés társas-társadalmi aspektusairól lásd még Kiss Paszkál tanulmányát, az érzelmi megközelítésekről pedig Gombos Katalin, Bányai Éva és Varga Katalin munkáját.
} 
dő gyerekeknek kevesebb barátjuk volt, és többet kötekedtek velük társaik, mint a tanulási zavarral nem küzdőkkel.

Al-Yagon és Mikulincer (2004) azt vizsgálták, hogy a tanulási zavarral küzdő és azzal nem rendelkező gyermekek kötődési stílusa milyen szerepet játszik magányosságérzésükben, koherencia érzékükben és iskolai teljesítményükben. A gyerekek koherencia érzékét olyan kérdésekkel mérték fel, melyek arra vonatkoztak, hogy valaki mennyire érti meg a környezetében történő eseményeket; milyen mértékben érez kontrollt az események felett, illetve hogy a különböző feladatokba mennyi erőfeszítést fektet, azaz a motivációt és az érdeklődést is feltárták. A kérdőíves kutatás eredményei szerint a tanulási zavaros gyermekek kevésbé biztonságosan kötődtek közeli kapcsolataikban, inkább az elkerülő és az ambivalens kötődési stílus volt rájuk jellemző. Továbbá az elvártaknak megfelelően a tanulási zavaros tanulók társaikhoz képest inkább érezték magukat magányosnak, ugyanakkor koherenciaérzékük és iskolai teljesítményük szignifikánsan gyengébb színvonalú volt. Mind a tanulási zavarral küzdő, mind az azzal nem küzdő gyerekek csoportjában összefüggés mutatkozott a kötődési stílusok és a magányosság, valamint a koherenciaérzék között. A biztonságos kötődési stílus például fordított irányú erős negatív korrelációt mutatott a magányosságérzéssel, míg a koherenciaérzékkel jelentős pozitív összefüggésben állt. Ez azt jelenti, hogy a biztonságos kötődési stílus mintegy protektiv faktorként funkcionál a csoportbeli marginalizálódás, az elmagányosodás tekintetében - a tanulási zavarral küzdő gyerekek esetében is. Ugyanakkor - a szocioemocionális alkalmazkodással ellentétben - a kötődési stílus nem állt összefüggésben a tanulmányi elömenetellel egyik csoportban sem.

Agaliotis és Kalyva (2008) a társas készségek egy jelentős szeletét, a nemverbális kommunikáció müködését vizsgálta tanulási zavarral küzdő gyerekeknél. Felmérték 36 tanulási zavaros és 36 nem tanulási zavaros tanuló kezdeményezett és válaszként adott nonverbális jelzéseinek gyakoriságát egy 40 perces szünet alatt. A fiatalabb (1-3. osztályos), tanulási zavarral küzdő gyerekek szignifikánsan kevesebb nemverbális kezdeményezéssel éltek, mint a tanulási zavarral nem küzdő társaik. Az idősebb tanulóknál (4-6. osztályig) a két csoport között nem mutatkozott ilyen eltérés. A tanulmány fontos feltételezése, hogy a tanulási zavarral küzdők - akiknek számos nyelvi készség gyakorlása nehézséget okoz - nemverbális skilljeinek (metakommunikatív készségeinek) (például mosoly, szemkontaktus-kezdeményezés, várakozás) fejlesztésével csökkenthetők lennének szociális deficitjeik.

További vizsgálatok arra is rámutattak, hogy a tanulási zavarral küzdők társaikhoz képest több agresszív és bomlasztó viselkedésformával jellemezhetőek (Sale és Carey, 1995), interperszonális konfliktusaikban nehezebben hoznak döntést (Agaliotis és Goudiras, 2004), kevesebb pozitív szociális készséget használnak (Newcomb et al., 1993), valamint serdülökorban több alkalmazkodási problémát mutatnak, mint kortársaik (Kupersmidt et al., 1990). 


\section{Példák a tanulási zavarok és a magatartászavarok kapcsolatáról}

Gyakori, hogy a felszínen, a látható szinten a magatartási zavar jelenik meg: a gyermek motorosan nyugtalan, figyelme könnyen elterelödik, feszült, türelmetlen, akár indulatos, dacos is lehet, vagy éppen meglassúbbodik, érdektelen. Ezek mögött a magatartási problémák mögött azonban gyakorta valamilyen érzelmi zavar és/vagy specifikus tanulási probléma áll (László, 2005). A legtöbb esetben, ha az okot, azaz az emocionális és/vagy a tanulási zavart, nehézséget kezeljük, javulnak, vagy akár meg is szünnek a viselkedéses problémák. Ha a környezet nem ismeri fel a lehetséges háttérmechanizmusokat, ördögi kör indulhat el, a gyermek a ráakasztott negatív címkétől nem tud megszabadulni, sőt azt egy idő után magára is érvényesnek tartja, elfogadja a környezet ítéletét: ő egy rossz, javíthatatlan gyerek, önértékelése torzul, hamis self (Winnicott, 1952/2004) épül ki. Az alapprobléma és a rárakódó magatartási zavarok pedig egymást erősítve tovább rontják a gyermek iskolai, közösségbeli, akár családbeli helyzetét, megítélését.

A következőkben néhány szemléletes példával érzékeltetjük a fentieket. Tamás esete: A hét és fél éves, 1. osztályos kisfiút az iskola küldte vizsgálatra a nevelési tanácsadóba. Az intézmény jelzése szerint Tamás lassú tempóval, sok betütévesztéssel, betücserékkel olvas. Teljesítményében szótorzítások, iránytévesztések fordulnak elő. Bizonytalan a relációs szókincs használata, a téri tájékozódás, a soralkotás, a szabályfelismerés. A tanórákon csendes, visszahúzódó, gyakran tűnik fáradtnak, bizonytalannak, sok magyarázatra, segítségre, biztatásra van szüksége.

Anamnézise korai, közvetlen születés utáni szeparációt, illetve későbbi jelentős családi traumát tartalmaz: az iskolakezdés előtti nyáron édesapja előtte akasztotta fel magát. Mozgás- és beszédfejlődése mater elmondása szerint normál ütemben haladt. Az édesanya elmondja, hogy Tamás már óvodába sem szeretett járni, ahogyan iskolába sem, úgy érzi, társai kiközösítik.

A szomatikusan fejlett kisfiú vizsgálati helyzetben szorongó, visszahúzódó, hallgatag volt. Gyakran látszott riadtnak, ha valamit elrontott, a szituációhoz képest inadekvát módon megijedt. Feladathelyzetben együttmüködő volt, figyelme tartós, stabil, azonban alacsony motivációs fokon mozgott. Pszichomotoros tempója meglassúbbodott. Beszédtempója is igen lassú, megnyúlt volt.

Intellektusa átlagos övezetbe esett. Lassan, akadozva, sok hibával olvasott, ami megnehezítette az instrukciók megértését, a feladat végrehajtását. A szabályfelismeréssel nehézkesen boldogult.

A pedagógiai vizsgálat szórt teljesítményprofilt mutatott: a tesztfeladatok közül a vizuális differenciálást, a vizuális tagolást, a vizuális emlékezetet, a szerialitást és az intermodális emlékezetet vizsgáló feladatokban jellemezték hibás válaszok. Meixner olvasólap-vizsgálat alapján észlelt hibák: $s z-z s ; n y$-ty; $b$-d; g-gy hangcserék, melyeknek lehetséges oka a téri tájékozódás és a vizuális emlékezet részképességek gyengesége. 
Átlagos intellektus talaján tehát több, az írás, olvasás részfolyamatait megalapozó terület jelentős elmaradása volt tapasztalható Tamásnál. A kisfiú pszichomotoros tempójának - feltehetően pszichés okok miatti - rendkívüli lassúsága ezeket a nehézségeket felerősítette, javulásukat/fejlesztésüket gátolta. Éppen ezért szemészeti kivizsgálása és elmaradás szerinti tantárgyi korrepetálása mellett - aktuális pszichés státuszát tekintve - további komplex (pszichológiai, pszichiátriai) kivizsgálását javasoltuk. Lényeges ilyen esetekben a fokozott pedagógiai megsegítés, a feltehetően a gyermekdepresszió kialakulása miatt meglassúbbodott pszichomotoros tempó tolerálása tanórai helyzetben.

Bence esete: A tíz és fél éves, 4. osztályos tanuló vizsgálatát szintén az iskola kérte a szülő támogatásával. A pedagógus jelzése szerint Bence az 1. osztály óta küzd komoly tanulási nehézségekkel, szinte minden tantárgyi területen gyengeségeket mutat. Lassú munkája, tanulás iránti motiválatlansága fokozza ezt. A gyermek iskolai viselkedése kapcsán továbbá kiemelendő, hogy nagyon játékos, figyelmét néhány percig sikerül fenntartani az adott feladatban, a külső tényezők folyamatosan befolyásolják és akadályozzák koncentrált munkáját. Bence a vizsgálat elvégzése előtt négy évig folyamatosan részesült mozgásfejlesztő foglalkozásokban, azonban azokról elmaradt, mert felvetődött az osztályismétlés és szakértői vizsgálat lehetőséges is.

Bence anamnéziséből kiemelendő, hogy már csecsemőként is igen nyugtalan, élénk gyermek volt. Mozgásfejlődéséből a kúszás-mászás szakaszai kimaradtak, beszédfejlődése megkésve indult. Az édesanya beszámolt arról, hogy Bence írásbeli feladataiban sok hibát vét, nehezen tud egy feladatra hosszabb ideig koncentrálni, gyakran lemarad az órai munkában. Az iskolában - mind tanórai, mind szünetbeli magatartásával gondok vannak.

A vizsgálat alatt kitủnik, hogy a szomatikusan fejlett gyermek nagymozgása igen koordinálatlan. A vizsgálat megkezdésekor rendkívül türelmetlen, aktívan explorálja a szobát, hirtelen mozdulataival el-eldönt tárgyakat, a labdát az ajtónak dobálja. Folyamatosan mocorog, nem tud nyugodtan ülni (dobol a lábával, tologatja az asztalt, gyakran iszik, a játékpolcról játékokat vesz le), hirtelen játéktevékenységgel szakítja meg feladatvégzését, melybe minduntalan vissza kell téríteni, ami csak erős motivációval, határozott, rövid felszólításokkal lehetséges. Gyakorta kezdeményez beszélgetést, vagy fel is áll és úgy lép ki a feladathelyzetből. Figyelme rendkívül fluktuáló. Pszichomotoros tempója hullámzó: hol lassú, máskor - a feladatvégzés rovására - gyors, felületes.

Intellektusa átlagos tartományba esik, jelentősebb pozitív túlsúllyal a performációs terület javára. Az egyes részpróbákban igen változó teljesítményt nyújtott. Rajzolás, másolás közben jobb kézzel, szabályos ceruzafogással, erős írásnyomatékkal, görcsös vonalvezetéssel dolgozik. Részletszegény emberrajzán aránytalanságok, torzítások figyelhetők meg. A vizuo-motoros koordinációt vizsgáló BenderB-próbában teljesítménye - az életkorában elvárhatóhoz képest - igen gyenge, leg- 
alább három éves elmaradást mutat. Nehézségek föként az orientációban és a pozíció helyes leképezésében mutatkoznak: problémás az ábrák egymáshoz való viszonyának megjelenítése is.

Pedagógiai vizsgálata rámutat, hogy számolása már százas körben is hibás, a csökkenő és a növekvő sorrendet keveri. Müveleteket nem minden esetben tud azonosítani, a szorzás, osztás még bevésés alatt áll. Műveletvégzésnél a számok sorrendjét felcseréli, sorrendet nem tart. Egyszerü szöveges feladatot segítséggel old meg. Helyiérték-fogalma kialakulatlan. Irás-olvasás vizsgálata is lassú tempót és sok hibát jelez. Olvasás alatt nyugtalan, szuszog, nyög. Beszéde nehezen érthető. Diktálás, illetve önálló fogalmazásírás közben a szavak egybeírása, az ékezetek elhagyása, egy-két betűcsere a jellemző. Másoláskor lényegesen kevesebb hibát vét.

A figyelem és a mozgáskoordináció zavarát mutató, átlagos intellektusú gyermeknél több, a matematikai készségek, valamint az olvasás és az írás részfolyamatait megalapozó területek jelentős elmaradása tünt ki. Teljesítménye alapján felmerült az organicitás (idegrendszeri érintettség) gyanúja, így a sajátos nevelési igény megállapítása vagy kizárása, illetve a gyógypedagógiai ellátás mérlegelése miatt szükséges további szakértői vizsgálata.

András esete: András már 15,3 éves, 9. osztályos amikor iskolája - a szülők egyetértésével - vizsgálatát kéri. Andrásnak elsős gimnazista koráig „kellett várnia”, amikor magyartanára észlelte és jelezte problémáit: „Dolgozataiban nagyon magas a helyesírási hibák száma, diszgráfiára utaló tüneteket vettem észre.” Az iskola szerette volna vizsgálatunk alapján megtudni, hogy Andrásnál fennáll-e részképesség-zavar.

A tanuló anamnéziséből kiemelendö, hogy az általános iskola első két évét logopédiai osztályban végezte. A későbbiekben ezután nem részesült problémacentrikus ellátásban (!). Az édesanya elmondása szerint András viselkedése „lobbanékony", korábban jártak a Vadaskert Gyermekkórházban is, ahol magatartászavart állapítottak meg a fiúnál, de kezelésben szintén nem részesült. Édesanyja elmondja, hogy fia sok hibával ír, idegen nyelvet nehezen tanul. Emiatt már általános iskolában konzultált a gyermek tanáraival, azonban kivizsgálásra nem került sor, András iskolai nehézségeit diagnosztizált magatartászavarára hárították.

A vizsgálat megállapításai szerint András együttműködő, motivált, kitartó, figyelmi kapacitása stabil, hosszantartó. Intellektusa normál tartományba esik, pozitív túlsúllyal a performációs terület javára. Gondolkodása meglehetősen konkrét síkon mozog: szómeghatározásnál gyakran csak példával szemléltet. Főfogalmat nehezen ad meg. Szóban nehézkesen nyilvánul meg, gyakran csak hiányos mondatokban válaszol, szómegtalálási nehézségek tapasztalhatók fogalmazásában. Balkezes, a vizuo-motoros koordinációt vizsgáló Benton-próbában átlagos teljesítményt nyújt, azaz megfelelő színvonalon képes vizuális benyomásokat felvenni, megtartani, emlékezetből feleleveníteni és motoros teljesítményében reprodukálni. Enyhe 
fokú torzítások az ún. széli formák emlékezet alapján történő leképezésében vannak, ami perifériás figyelmének gyengeségére utal.

Pedagógiai vizsgálata rámutatott, hogy András helyesírásában - az olvasással szinkronban - az időtartam érzékelésével összefüggő és a szövegemlékezeti hibák jelennek meg a legnagyobb mértékben. Erösen rontja a helyesírási teljesítményt a helyesírási szabályok következetlen alkalmazása, a szóelemző írásmód hiánya. Ugyanakkor speciális hibatípusok - úgy mint szeriális hiba, szótagkihagyás, a szóhatár érzékelésének bizonytalansága - elenyésző mértékben fordulnak elő. A tagolási hibák közül az összetett szavak írásánál és a mondat belső tagolásánál mutatkozik komolyabb gyengeség.

Valószínüleg a jelenlegi helyzethez hozzájárul, hogy az általános iskola logopédiai osztályában eltöltött két tanév után a gyermek semmilyen fejlesztö vagy reedukációs foglalkozáson nem vett részt. A korai nyelvfejlődési zavarra alapozódó helyesírás-gyengeségét, tanulási nehézségeit semmilyen formában nem kezelték, az iskola és a család is figyelmetlen, nehezen kezelhetö gyermekként „,könyvelte” el. András egyre intenzívebben tagadta meg a tanulást, feladta a próbálkozást, így még inkább lemaradt. Ennek eredményeképpen a részképesség-gyengeségek mellett a tanulmányi teljesítményt tovább rontotta a gyakorlottság és a motiváció gyengesége. A vizsgálatot kérő magyartanár részletes fejlesztési javaslatunk alapján vállalta a beilleszkedési-tanulási-magatartási nehézséggel küzdő serdülő célzott korrepetálását. Javasoltuk továbbá az 1993-as LXXIX. Törvény a Közoktatásról 30. § (9) bekezdése alapján magyar nyelvtan és idegen nyelv tantárgyban a helyesírás tantárgyrész követelményeiben minősítés alóli felmentését, valamint valamennyi tantárgy esetén az ellenőrzéskor, az értékelés különböző alkalmaikor az idő megnövelését, írásbeli feladatok helyett pedig szóbeli feleletek alkalmazását.

A fenti esetrészletekből is érzékelhető, akár a tanulási zavarra épül a magatartászavar, akár a magatartászavar jár együtt tanulási nehézségekkel, a pedagógusnak a szokottól eltérően, újszerüen kell viselkednie. Eközben felkészültsége mellett saját személyisége lehet a támasza: önismerete, önmegfigyelése és ennek talaján hitelessége, spontaneitása (Buda, 1999). Ehhez egyre többször kell pedagógusainknak folyamodnia, hiszen a statisztikák szerint a tanulási nehézségek aránya a különböző fogyatékosságokkal együtt hazánkban megközelíti a 10 százalékot (Csányi, 2007), $\mathrm{s}$ akkor még a társuló magatartási problémák okozta nehézségeket és a diagnosztikai kritériumokat el nem érő, de problémás tanulókat nem is vettük számba.

\section{Prevenció}

A fentiekből is kiderül, hogy a tanulási és a magatartási zavarok olyan szorosan összefonódnak, hogy együttes jelenlétük kölcsönösen erősíti a másikat (Sutherland et al., 2008). Ez azt a kedvezötlen következményt hordozza magában, hogy még inkább elmélyül a probléma. Egyben ez azt is jelenti, hogy bármely terület kedvező 
irányú befolyásolása maga után vonhatja a másik terület pozitív irányú változását, kompenzálódását (Felleginé, 2004). Például Bennett és munkatársai (Bennett et al., 2003) kanadai óvodás és első gyerekeket követett nyomon 30 hónapon keresztül. Eredményeik szerint az olvasási képesség fejlődése csökkentette a viselkedési problémák előfordulását.

A magatartási zavarok megelőzésére most részletesen nem térünk ki. Urbán és munkatársai (Urbán et al., 2007) átfogóan áttekintik az agresszív és antiszociális viselkedés univerzális, szelektív és indikált prevenciós programjait. Jelen tanulmányban csak azt emeljük ki, hogy föként az iskolai színtérre épülő programok tartalmazzák a nyelvi készségek fejlesztését (például The EARLY ALLIANCE prevention Trial: Prinz et al., 2000).

Egy görög szerzőpáros (Kalyva és Agaliotis, 2009) pedig egy általuk kifejlesztett intervencióval (segítő beavatkozással) erősítette a tanulási zavaros gyerekek szociális képességeit: egy hónapig minden héten kétszer tíz perces történetet hallgattak meg a gyerekek, melyben egy konfliktus és az arra való megfelelő szociális reakció szerepelt. Az eredmények szerint ezek az ún. társas történetek hatékonynak bizonyultak az interperszonális konfliktusokban a megfelelő megoldási stratégiák kiválasztásában. A beavatkozás előtt a tanulási zavaros tanulók főként elkerülő és ellenséges konfliktuskezelő stratégiákat alkalmaztak, míg alapvetően pozitív stratégiákat követtek az intervenció után a beavatkozásban nem részesülő kontraszt csoporthoz képest. Mi több a tanári értékelés szerint is szignifikánsan kevesebb nem megfelelő társas reakciót mutattak a beavatkozás után. Az eredmények megerősítik a tanulási zavarokkal küzdő gyerekek esetében is a különböző konfliktusés agressziókezelési intervenciók létjogosultságát.

A tanulási zavarral küzdő gyerekek társas kapcsolatainak mintázata (lásd fent) arra hívja fel a figyelmet, hogy fontos az oktatáspolitikának arra is hangsúlyt helyeznie, hogy a tanulási nehézséggel küzdők támogató kortárskapcsolatait fejleszszék az iskolai környezetben.

Külföldön például többféle iskolai prevenciós program is arra épül, hogy ún. funkcionális és strukturális analízissel feltárják, elemzik és az érintetteknek részletesen visszajelzik azt a sajátos interakciót, amely az adott osztály, csoport jellemzői és a kimenet (tanulmányi eredmény, a tanárok megítélése stb.) között fennállnak (Stichter, 2001; Stichter és Conroy, 2005). Felmérik például azokat a tényezőket, melyek az adott közösségben felkeltik (például filmklub) és fenntartják a tanulók érdeklődését (például osztályújság szerkesztése), illetve bizonyos kívánatos viselkedését (például közösségi aktivitás). Közben megfigyelik az olyan jellegzetességeket is, mint például a pedagógus által adott feladatok nehézsége, vagy a verbális és nonverbális jutalmazás, pozitív visszajelzés mennyisége, illetve az osztály zajszintjének váltakozása. Ezt a fajta eljárástechnikát hasznosan lehet alkalmazni a tanulási és/vagy magatartási zavarral küzdő tanulókat integráló osztályok esetében is (Sutherland et al., 2008). 
Végül Al-Yagon és Mikulincer (2004) kötődési kutatásának gyakorlati felvetését emeljük ki, mely szerint, ha a fejlődésbeli elmaradás, így a későbbi tanulási zavar kockázata akár a legkorábbi időszakban is felmerül, érdemes attachment alapú - azaz a biztos kötődést fejlesztő, stabilizáló - intervenciós technikákat bevetni. Ezek a beavatkozások, mint korai preventív eljárások, a szülö-gyermek kapcsolat minőségének fejlesztésére irányulnának a biztos kötődési stílus elemeit facilitálva. Ezzel a megelőzés egy igen érzékeny periódusban - egyben a későbbiekre nézve is magas hatásfokkal - történhetne meg.

\section{Irodalom}

1993. évi LXXIX. törvény a közoktatásról 2007. szeptember 1-jétöl hatályos szövege.

Agaliotis, I., Goudiras, D. (2004): A profile of interpersonal conflict resolution of children with learning disabilities. Learning Disabilities: A Contemporary Journal, (2) 2, 15-29.

Agaliotis, I., Kalyva, E. (2008): Nonverbal social interaction skills of children with learning disabilities. Research in Developmental Disabilities, (29) 1, 1-10.

Al-Yagon, M., Mikulincer, M. (2004): Patterns of Close Relationships and Socioemotional and Academic Adjustment Among School-Age Children with Learning Disabilities. Learning Disabilities Research and Practice, (19) 1, 12-19.

Barkley, R. A. (1990): Attention-Deficit Hyperactivity Disorder. The Guilford Press, New York.

Bender, W. N., Wall, M. (1994): Social-emotional development of students with learning disabilities. Learning Disabilities Quarterly, (17) 4, 323-341.

Bennett, K. J., Brown, K. S., Boyle, M., Racine, Y., Offord, D. (2003): Does low reading achievement at school entry cause conduct problems? Social Science and Medicine, (56) 12, 2443-2448.

Berk, R. A. (1983): Learning disabilities as a category of underachievement. In: Fox, L. H. - Brody, L. - Tobin, D. (Eds.): Learning disabled gifted children: Identification and programming. University Park Press, Baltimore, 51-76.

Berlin, L., Bohlin, G. (2002): Response Inhibition, Hyperactivity, and Conduct Problems Among Preschool Children. Journal of Clinical Child \& Adolescent Psychology, (31) 2, 242-252.

BNO-10 Zsebkönyv DSM-IV meghatározásokkal (1998): Animula Egyesület, Budapest.

Bödör Jenö (1991): Korrekciós nevelés. Tankönyvkiadó, Budapest.

Brocki, K. C., Nyberg, L., Thorell, L. B., Bohlin, G. (2007): Early concurrent and longitudinal symptoms of ADHD and ODD: relations to different types of inhibitory control and working memory. Journal of Child Psychology and Psychiatry, (48) 10, 10331041.

Buda Béla (1999): Viselkedészavar, konfliktus, problémamegoldás az iskolában. In: Fehér Irén (szerk.): Pedagógia és pszichológia. Comenius, Pécs, 173-183.

Carlson, C. I. (1987): Social interaction goals and strategies of children with learning disabilities. Journal of Learning Disabilities, (20) 5, 306-311. 
Clark, C., Prior, M., Kinsella, G. (2002): The relationship between executive function abilities, adaptive behaviour, and academic achievement in children with externalising behaviour problems. Journal of Child Psychology and Psychiatry, (43) 6, 785-796.

Culbertson, J. L. (1998): Learning disabilities. In: Ollendick, T. H. - Hersen, M. (Eds.): Handbook of child psychopathology. Plenum Press, New York, 117-156.

Csányi Yvonne (1991): Integráció. Új Pedagógiai Szemle, 12. sz. 38-47.

Csányi Yvonne (2000): A speciális nevelési szükségletü gyermekek. In: Illyés Sándor (szerk.): Gyógypedagógiai alapismeretek. BGGYTF, Budapest, 377-408.

CsányiYvonne (2007): Helyi adatgyüjtés a sajátos nevelési igényü gyermekek körében egy OECD-projekt keretében. Új Pedagógiai Szemle, 7. sz. 56-67.

Csépe Valéria (2005): Kognitív fejlödés-neuropszichológia. Gondolat Kiadó, Budapest.

DSM-IV Text Revision. A DSM-IV módositott szövege (2001): Animula Egyesület, Budapest.

Equity in Education. Students with Disabilities, Learning Difficulties and Disadvantages. (2004). OECD, Párizs, 165.

Feigin, J., Meisgeier, C. (1987): Learning disabilities and critical social and behavioral issues: A review. Journal of Reading, Writing, and Learning Disabilities, (3) 3, 259-274.

Felleginé Takács Anna (2004): Problémás tanulók, okok és megoldási javaslatok. In: N. Kollár Katalin - Szabó Éva (szerk.): Pszichológia Pedagógusoknak. Osiris Kiadó, Budapest, 472-496.

Fónagy, P., Target, M. (2005): Pszichoanalitikus elméletek a fejlödési pszichopatológia tükrében. Gondolat Kiadó, Budapest, 335-348.

Fritz, A. (1992/1984): Minimális cerebrális diszfunkciós gyermekek tanulási gyengeségének kognitív és motivációs okai. In: Torda Ágnes (szerk.): Szemelvények a tanulási zavarok köréböl. Tankönyvkiadó, Budapest, 31-52.

Gádoros Júlia (1996): Szociodemográfiai rizikótényezők vizsgálata Gyermekviselkedési Kérdöív alkalmazásával. Psychiatria Hungarica, (11) 2, 147-165.

Geisthardt, C., Munsch, J. (1996): Coping with School Stress: A Compariosm of Adolescents With and Without Learning Disabilities. Journal of Learning Disabilities, (29) 3 , 287-296.

Giancola, P. R., Mezzich, A. C. (2000): Executive cognitive functioning mediates the relation between language competence and antisocial behavior in conduct-disordered adolescent females. Aggressive Behavior, (26) 5, 359-375.

Gilmour, J., Hill, B., Place, M., Skuse, D. H. (2004): Social communication deficits in conduct disorder: a clinical and community survey. Journal of Child Psychology and Psychiatry, (45) 5, 967-978

Gyarmathy Éva (1998): A tanulási zavarok szindróma a szakirodalomban. Új Pedagógiai Szemle, 10. sz. 59-68.

Gyarmathy Éva (2007): Diszlexia. A specifikus tanítási zavar. Lélekben Otthon Kiadó, Budapest.

György Judit (1978): A „,nehezen nevelhetö” gyermek. Medicina Kiadó, Budapest.

Holt, J. (1991): Iskolai kudarcok. Gondolat Kiadó, Budapest. 
Hughes, C., Dunn, J., White, A. (1998): Trick or treat? Uneven understanding of mind and emotion and executive dysfunction in ,hard-to-manage" preschoolers. Journal of Child Psychology and Psychiatry, (39) 981-994.

Hughes, C., Ensor, R. (2007): Positive and protective: effects of early theory of mind on problem behaviors in at-risk preschoolers. Journal of Child Psychology and Psychiatry, (48) 10, 1025-1032.

Hughes, C., Ensor, R. (2008): Does Executive Function Matter for Preschoolers' Problem Behaviors? Journal of Abnormal Child Psychology, (36) 1, 1-14.

International Standard Classification of Education, (1997). Letöltve: http://www.unesco.org/education/information/nfsunesco/doc/isced_1997.htm

Kalyva, E., Agaliotis, I. (2009): Can social stories enhance the interpersonal conflict resolution skills of children with LD? Research in Developmental Disabilities, (30) 1, 192202.

Kirk, S. A., Bateman, B. (1962): Diagnosis and remediation of learning disabilities. Exceptional Children, (29) 2, 73-78.

Kupersmidt, J. B., Coie, J. D., Dodge, K. A. (1990): The role of poor peer relationships in the development of disorder. In: Asher, S. R. - Coie, J. D. (Eds.): Peer rejection in childhood. Cambridge University Press, Cambridge, 274-308.

László Zsuzsa (2005): Hiperaktív gyerekek az osztályban. In: Ligeti Csákné - Medgyes Sándorné - Szontagh Pál (szerk.): Pedagógiai kaleidoszkóp. Budapesti Pedagógusok Szakmai Szervezete, Budapest, 64-67.

Loeber, R., Burke, J. D., Lahey, B. B., Winters, A., Zera, M. (2000): Oppositional defiant and conduct disorder: a review of past ten years. Part I. Journal of the American Academy of Adolescent Psychiatry, (39) 12, 1468-1484.

Márkus Attila, Tomasovszki László, Barczi Judit (2000): Diszkalkulia (dyscalculia - DC) és a figyelemzavar-hiperaktivitás szindróma (Attention Deficit with Hyperactivity ADHD). Magyar Pszichológiai Szemle, 4. sz. 567-582.

Martlew, M., Hodson, J. (1991): Children with mild learning difficulties in an integrated and in a special school: Comparisons of behaviour, teasing and teachers' attitudes. British Journal of Educational Psychology, (61) 3, 355-372.

Moffitt, T. E. (1993): Adolescence-limited and life-course persistent antisocial behavior: a developmental taxonomy. Psychological Review, (100) 4, 674-701.

Moffitt, T. E., Caspi, A. (2001): Childhood predictors differentiate life-course persistent and adolescence-limited antisocial pathways among males and females. Development and Psychopathology, (13) 2, 355-375.

Morrison, G. M., Cosden, M. A. (1997): Risk, resilience and adjustment of individuals with learning disabilities. Learning Disabilities Quarterly, (20) 4, 43-60.

Newcomb, A. F., Bukowski, W. M., Pattee, L. (1993): Children's peer relations: a metaanalytic review of popular, rejected, neglected, controversial and average sociometric status. Psychological Bulletin, (113) 1, 99-128.

Perczel Forintos Dóra, Kiss Zsófia, Ajtay Gyöngyi (2005): Kérdőivek, becslőskálák a klinikai pszichológiában. OPNI, Budapest, 201-209. 
Perner, J., Winfried, K., Barchfeld, P. (2002): Executive Control and Higher-Order Theory of Mind in Children at Risk of ADHD. Infant and Child Development, (11) 2, 141-158.

Porkolábné Balogh Katalin (2002): A korai prevenciós fejlesztés. In: Martonné Tamás Márta (szerk.): Fejlesztő pedagógia. ELTE Eötvös Kiadó, Budapest, 11-31.

Prinz, R. J., Dumas, J. E., Smith, E. P., Laughlin, J. E. (2000): The EARLY ALLIANCE Prevention Trial - A Dual Design to Test Reduction of Risk for Conduct Problems, Substance Abuse, and School Failure in Childhood. Controlled Clinical Trials, (2) 3, 286-302.

Raaijmakers, M. A. J., Smidts, D. P., Sergeant, J. A., Maassen, G. H., Posthumus, J. A., Engeland, H., Matthys, W. (2008): Executive Functions in Preschool Children with Aggressive Behavior: Impairments in Inhibitory Control. Journal of Abnormal Child Psychology, (36) 7, 1097-1107.

Raine, A., Yaralian, P. S., Reynolds, C., Venables, P. H., Mednick, S. A. (2002): Spatial but not verbal cognitive deficits at age 3 years in persistently antisocial individuals. Development Psychopathology, (14) 1, 25-44.

Raine, A., Moffitt, T. E., Caspi, A., Loeber, R., Southamer-Loeber, M., Lynam, D. (2005): Neurocognitive impairments in boys on the life-course persistent antisocial path. Journal of Abnormal Psychology, (114) 1, 38-49.

Ranschburg Jenő (1998): Pszichológiai rendellenességek gyermekkorban. Nemzeti Tankönyvkiadó, Budapest.

Richters, J. E., Arnold, L. E., Jensen, P. S. (1995): NIMH Collaborative Multisite Multimodal Treatment Study of Children with ADHD: I. Background and rationale. Journal of The American Academy of Child and Adolescent Psychiatry, (34) 8, 987-1000.

Sale, P., Carey, D. (1995): The sociometric status of students with disabilities in a fullinclusion school. Exceptional Children, (62) 1, 6-19.

Sauvageot, B., Métellus, J. (2006): Hurrá, diszlexia! K.U.K. Kiadó, Budapest.

Séguin, J. R., Arseneault, L., Boulerice, B., Harden, P. W., Tremblay, R. E. (2002): Response perseveration in adolescent boys with stable and unstable histories of physical aggression: the role of underlying processes. Journal of Child Psychology and Psychiatry, (43) 4, 481-494.

Selikowitz, M. (1997): Diszlexia és egyéb tanulási nehézségek. Medicina Kiadó, Budapest.

Spafford, C. S., Grosser, G. S. (1993): The social misperception syndrome in children with learning disabilities: Social causes versus neurological variables. Journal of Learning Disabilities, (26) 3, 178-198.

Stichter, J. P. (2001): Functional analysis: The use of analogues in applied settings. Focus on Autism and Other Developmental Disabilities, (16) 4, 232-239.

Stichter, J. P., Conroy, M. (2005): Structural analysis in natural settings: A responsive functional assessment strategy. Journal of Behavioral Education, (14) 1, 19-34.

Sutherland, K. S., Lewis-Palmer, T., Stichter, J., Morgan, P. L. (2008): Examining the Influence of Teacher Behavior and Classroom Context on the Behavioral and Academic Outcomes for Students With Emotional or Behavioral Disorders. The Journal of Special Education, (41) 4, 223-233. 
Swanson, H. L., Jerman, O. (2007): The influence of working memory on reading growth in subgroups of children with reading disabilities. Journal of Experimental Child Psychology, (96) 4, 249-283.

Swanson, L., Kim, K. (2007): Working memory, short-term memory, and naming speed as predictors of children's mathematical performance. Intelligence, (35) 1, 151-168.

Swanson, H. L., Siegel, L. (2001): Learning disabilities as a working memory deficit. Issues in Education: Contributions of Educational Psychology, (7) 1, 1-49.

Trzesniewski, K. H., Moffitt, T. E., Caspi, A., Taylor, A., Maughan, B. (2006): Revisiting the association between reading achievemtn and antisocial behavior: new evidence of an environmental explanation from a twin study. Child Development, (77) 1, 72-88.

Urbán Róbert, Buda Béla, Hevesi Krisztina, Kökönyei Gyöngyi, Nagy Henriett, Rigó Adrien, V. Komlósi Annamária, Várnai Dóra (2007): Mentális egészségfejlesztési stratégia pozitiv egészségfejlesztés és primer prevenció. Országos Egészségfejlesztési Intézet, Budapest.

Vikár György (1980): A fiatalkor válságai. Gondolat Kiadó, Budapest.

Wenz-Gross, M., Siperstein, G. N. (1998): Students with learning problems at risk in middle school: Stress, social support and adjustment. Exceptional Children, (65) 1, 91100.

Willcutt, E. G., Betjemann, R. S., Wadsworth, S. J., Samuelsson, S., Corley, R., DeFries, J. C., Byrne, B., Pennington, B. F., Olson, R. K. (2007): Preschool twin study of the relation between attention-deficit/hyperactivity disorder and prereading skills. Reading and Writing, (20) 1-2, 103-125.

Willcutt, E. G., Pennington, B. F. (2000): Psychiatric Comorbidity in Children and Adolescents with Reading Disability. Journal of Child Psychology and Psychiatry, (41) 8, 1039-1048.

Willcutt, E. G., Pennington, B. F., Boada, R., Ogline, J. S., Tunick, R. A., Chhabildas, N. A., Olson, R. K (2001): A comparison of the cognitive deficits in reading disability and attention-deficit/hyperactivity disorder. Journal of Abnormal Psychology, (110) 1, $157-172$.

Winnicott, D. W. (2004/1952): Pszichózis és gyermekgondozás. In: Péley Bernedette (Szerk.): A kapcsolatban bontakozó lélek. Új Mandátum, Budapest, 104-113.

Wolfensberger-Haessing, C. (1985/1992): A szeriális észlelési gyengeség, egy kevéssé ismert zavar POS gyermekeknél. In: Torda Ágnes (szerk.): Szemelvények a tanulási zavarok köréböl. Tankönyvkiadó, Budapest, 133-140.

Zsidi Zoltán (1997): Hagyjuk sorsára? Magatartászavar fiatal korban. Nemzeti Tankönyvkiadó, Budapest. 